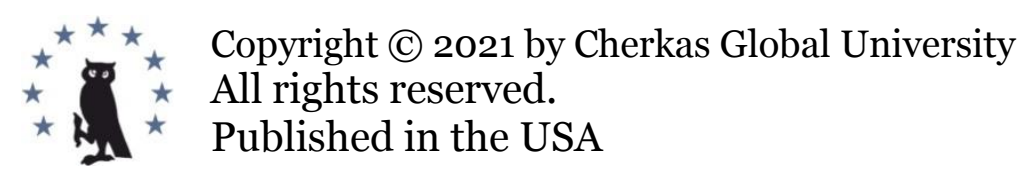

European Journal of Contemporary Education

E-ISSN 2305-6746

2021. 10(4): 1027-1041

DOI: $10.13187 /$ jced.2021.4.1027

https://ejce.cherkasgu.press

IMPORTANT NOTICE! Any copying, reproduction, distribution, republication (in whole or in part), or otherwise commercial use of this work in violation of the author(s) rights will be prosecuted in accordance with international law. The use of hyperlinks to the work will not be considered copyright infringement.

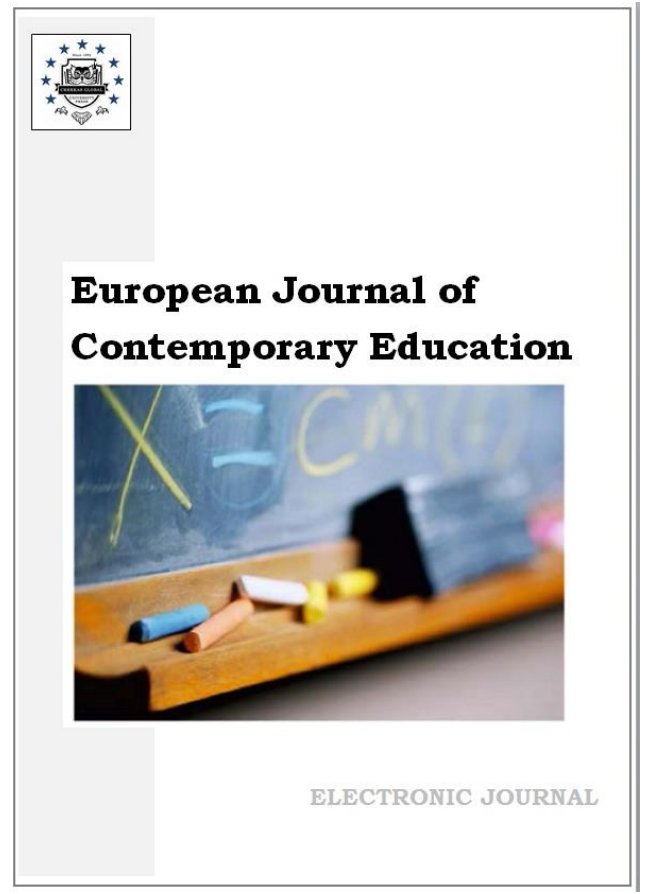

\title{
High School Principals' Situational Leadership and Its Relationship with Teachers' Achievement Motivation
}

\author{
Al-Zoubi H. Zohair a , *, Maberah Shooroq ${ }^{\mathrm{b}}$, Darawsha Najwa ${ }^{\mathrm{b}}$, Bany M. Issa Hytham ${ }^{\text {a }}$ \\ a Department of Educational foundations and Administration, Faculty of Educational Sciences, \\ the Hashemite University, Jordan \\ b Faculty of Educational Sciences, Jadara University, Jordan
}

\begin{abstract}
The study aimed to identify situational positional leadership and its relationship with the motivation of achievement in the city of Amman, from the point of view of teachers. It used the descriptive research method with a sample of 445 teachers, collecting information first on situational leadership second on the motivation of achievement. The findings indicated that the principals exercised a high level of situational leadership. It also showed that there were no significant differences in the level of situational leadership by gender, qualifications, and years of experience, while the results showed that there are statistically significant differences in the level of participative leadership in favour of female teachers. The results show that high school teachers' motivation for achievement in the first Directorate of Education of Amman was high. There are statistically significant differences in the level of motivation of achievement by gender in favour of females. Also, there are statistically significant differences in teachers' motivation of achievement by qualifications, in favour of science teachers. At the same time, there are statistically significant differences in the level of teachers' motivation of achievement by years of experience, in favour of teachers with 5-10 years of experience. Finally, the results show a positive correlation between the degree of situational leadership and the level of teachers' motivation of achievement. The authors recommend arranging courses for principals to inform them of the importance, objectives, and dimensions of situational leadership and focusing on the directive leadership style based on providing instruction and guidance.
\end{abstract}

Keywords: situational leadership, motivation of achievement, school principals.

\footnotetext{
${ }^{*}$ Corresponding author

E-mail addresses: zohair971@hu.edu.jo (A.H. Zohair), hytham@hu.edu.jo (B.M. Issa Hytham)
} 


\section{Introduction}

Leadership is important and there is an increasing need in all societies, particularly developing societies, for leaders capable of organizing, developing and managing institutions to improve performance and achievement to keep pace with the more developed societies (Al-Qaisi, 2010). The concept of leadership and its forms and patterns have varied over time (Al-Mu'aqash, 2007); leadership style is one of the key elements contributing to shaping the character of functional relationships within different institutions (Saud, 2009).

Situational leadership is one of the latest contributions to educational administrative thought's ideas, concepts, and contents (Al-Babtin, 2013). It is an important element in the life of the human being, the worker and the employee. This type of leadership adapts to the situation facing the leader, who requires awareness, organization, accuracy and patience in meeting the situation imposed on him if he is to deal positively and to the benefit of the institution (Avci, 2016).

The situational leader must have several skills, humane and cognitive, in order to face, adopt, decide and be able to make decisions and solve problems positively in educational and other institutions (Al-Mutairi, 2013). Solving problems requires conscious leadership through knowledge, follow-up and wise supervision (Dari, Division, 2020). The principal of the school is the educational leader who has overall of his school. Leadership and attitude often affect the quality of the educational process and may arise from the characteristics of an influential leader in the group's activity (Abkar, 2015).

The school principal is an educational leader, assigned to vital tasks, and with a major and effective role in improving the educational process (Ajarma, 2012). Achieving the school's objectives and mission depends on how the principal manages his school and faces the administrative problems arising from different situations. Crucial to successful leadership is the leader's personality, building positive relationships with the teachers and other employees, improving working conditions, and solving administrative problems and making the right decision (Naseer, 2017).

There are many definitions of situational leadership. Al-Tamimi (2006) pointed out that it focuses on the nature of the relationship between leaders and members. The leader works to change his leadership style according to the abilities and inclinations of the group members. An individual may be a group leader in a certain situation but not necessarily a leader in another situation. A leader cannot appear unless he is prepared to recognize social situations.

Al-Sarafi (2009) defined situational leadership as the result of the interaction between the attributes of the leader and the members and the characteristics of the task or situation. It is an important type of leadership because of its implications for the institution through the use of available resources. Morsi (2010) pointed out that it is a style of leadership that reacts to the quality of the situation; for example, leadership during wartime, crisis or emergency is different from leadership in times of peace and prosperity. Similarly, leadership in a given institution varies from one situation to another in guiding individuals to achieve the institutional goal. Al-Ruwaili (2012) also stated that situational leadership is one of the modern trends in an administration that calls for dealing with each situation as it arises, taking account of the environmental conditions and determining which administrative methods have the best chance of success.

The concept of educational situational leadership is based on applying a scientific approach to solving the problems of school education; realism and scientific accuracy are based on knowledge of the function required according to the nature of the situation (Zahrani, 2008). Situational leadership provides employees with objective methods to solve problems that are beyond their personal experience (Faraj, 2016). It also contributes to the participation of teachers in solving problems that are particularly important in their classrooms, and focuses on obtaining scientific information, with the opportunity for dialogue, collective participation, consultative development and exchange of views (Nawafala, 2002).

Researchers have identified a range of features that a situational leader must have, including the democratic nature of school renewal and the use of an in-service training method for teachers to raise their academic level and increase their training skills (Haji, 1998). Concern for all aspects of the educational administrative process should be comprehensive and flexible; the task of leadership is to identify important situations and find appropriate solutions (Al-Nawafa, 2002). Situational leadership also considers humanitarian needs, the highest material objectives, individual differences, and public and private relationships with each other and with the 
surrounding environment (Al-Harbi, 2008). It pays attention to the philosophy and requirements of the educational organization, through its organizational structure and regulations, its traditions and customs, the direction of the institution and national objectives (Al-Masherfi, 2015). It enables leaders to develop technical, human and intellectual skills as a challenge to the analytical ability of leaders (Al-Shahrani, 2013). It calls for innovation, creativity and ideas that can be optimally responsive to employees and motivate them to invest their abilities and talents to achieve the objectives of the educational institution (Hammadat, 2017). It pays attention to human relationships within the limits of employment or work (Al-Omari, 2009).

The situational leader is responsible for the effectiveness of the comprehensive evaluation of all aspects of educational work, whether in relation to teachers, workers, students, curriculum, educational level, school environment, schools' relationship with society or the difficulties he faces. The situational leader acknowledges different leadership trends according to the maturity of members of the school community, including the directive and persuasive trends (Issa, 1997).

Principals who have internal motivations towards performance and even employees, who are risk-taking and tend to take on difficult tasks, are more creative, distinguished, determined and ambitious to achieve success, and have enthusiasm, self-confidence and a desire to learn, excel, and take responsibility (Tabshi, 2007). They work continuously, make additional efforts, are not afraid, insist on challenging threats and are flexible in dealing with situations, focusing on goal-setting and performance with internal determination and perseverance to accomplish their work (Tartori, 2006).

The administrator has to continue achieving excellence in work, and this may motivate him to continue following developments in the organization and develop distinct options to deal with them. When the employees feel their presence according to a distinct institution, this may be reflected in the level of their performance and motivation towards work (Hammad, 2016).

The concept of motivation is an important aspect of psychology, because of its association in explaining human behaviours; Al-Qurashi (2012) indicated that the cause of human activity and its diversity is primarily the multiplicity of motives, through the corresponding multiplicity of needs, desires and objectives. Al-Yousef (2010) said that the need for achievement is linked to the components of a person's basic personality and motivation.

The concept of motivation refers to a process that begins with a physiological, psychological or social deficiency or need that stimulates behaviour to work towards eliminating that deficiency (Harem, 2004). Psychologists' definitions of motivation vary as a result of the diversity of their functions. For example, Imran (2004) defines it as a set of feelings that drive the learner to engage in learning activities that lead to the achievement of the desired goals. It is a fundamental necessity for learning to occur. Yaqoob (2012) defined it as a process, or a series of processes, that stimulate and maintain targeted behaviour in order to achieve an end that the individual needs. This is achieved through factors emanating from the individual's own self, or from the physical and psychological environment surrounding him, such as physical incentives, suspense, curiosity, presentation of meaningful stories, or the use of methods of attention when providing an experience. Al-Farmawi (2004) defined motivation as a psychological and physiological force that stems from the soul, driven by internal and external stimuli, leading to an urgent desire to carry out a particular activity and continue it until this desire is realized. Gover and Petri (2004) defined it as conditions that facilitate, direct and assist behavioural continuity until responses are achieved, in the sense that they are a series of processes that trigger, formulate, maintain and ultimately stop targeted behaviour. Al-Halool (2008) said it is a hypothetical construct that expresses a situation in which the organism lives, stimulates, and directs it towards a particular goal, while Azzam (2010) refers to motivation as what initiates the behaviour, stimulates it, keeps it going, directs it, and works to stop it.

Based on previous definitions, the authors define motivation as the set of needs, desires and interests that individuals look to achieve in institutional work, with a range of incentives that raise these aspirations among individuals. In other words, the teacher needs to behave in a manner to achieve his goals in light of the objectives of the institution.

Motivation is linked to the individual's interests and objectives, including achievement motives, in fulfilling his or her functions, which are health and psychological markers (Farwaj, 2011). Al-Qurashi (2012) believes that the achievement motive is the desire to succeed with full appreciation of life's competitions, to meet the challenges efficiently, to avoid failure and raise selfesteem and social appreciation, as well as avoiding blame and punishment. 
Al-Halool (2011) pointed out that the achievement motive is to succeed in what others consider difficult, to control the physical and social environment, to control and handle ideas, to regulate, to speed performance, to be independent, to overcome obstacles, to achieve standards of excellence and self-superiority, to compete with others, to excel, to have self-esteem and to appreciate the successful exercise of power. Al-Mutairi (2005) noted that it is the ability of the individual to achieve and accomplish something difficult and control the physical topics or organize ideas and complete them as quickly as possible, to overcome obstacles and reach the highest level of achievement in the required tasks. Barkat and Hasan (2011) explained that the achievement motive is the triple compound of the motive's power, the likelihood of the individual's success and the motive itself, with its value to the individual, and its clarity. Ayasra (2006) clarifies it as a network system of cognitive, emotional, directed, or associated relationships striving to achieve the level of excellence. As defined by Al-Widyan (2000), it is the feeling of satisfaction and comfort when something is accomplished or finding new things that did not exist before. Al-Zyadat (2004) also showed that the achievement motive represents conservative behaviour with certain levels of excellence.

Individuals with a motive to achieve work harder than others and win more success in their lives; when compared to those with the same level of mental capacity but allow achievement motive, they score high levels of achievement and problem solving, and are more influential in society (Santrock, 2003).

The authors believe that the achievement motive for teachers in schools is linked to several factors, including self-realization and ongoing self-and functional goals, which are reflected in their level of performance and satisfaction with work, a sense of excellence and professionalism, and a desire for competition and success in their various fields of school and community work.

The achievement motive of the teacher lies in his interest in education and development, which is an internal condition for greater effort and activity and continuity, and the presence of motivation shared by the school administration in its realization (Imran, 2000). People who have strong achievement motives differ from those who have low motivation; those who have strong motives are persistent, highly qualified in performance, have a greater understanding of themselves, and are willing to express themselves and resist external pressure (Khalifa, 1993). They also work hard in scientific experiments, learn quickly, their school performance is somewhat better, and even after the IQ is excluded, they do their best, especially when the result of this performance is placed on their records, and they are more resistant to external pressure (Al-Qurashi, 2012). The personality traits of those who have the achievement motive also include self-confidence, preference for individual responsibility, knowing the detailed results of their work, and choosing experts over friends as business partners (Al-Makahla, 2014). They also enjoy moderate risk in situations that depend on their own abilities, rather than attitudes based on luck and birth. They are individuals who have high scores on the scale of the achievement motive, whose families provide them with sensory incentives to arouse their curiosity; the relationship between the individual and the nature of the family affects the motive to develop or suppress the desire to achieve (Azzam, 2010).

A number of researchers have conducted studies on situational leadership, including Al-Aghbari (1998), whose results indicated that the delegate and participative leadership patterns are the most significant, as practiced by a sample of the principals and agents of schools. Bailey and Ireh (1999) also conducted a study whose results showed that the province's spending on each student was positively linked to adaptive patterns and situational leadership. It also indicated that the years of administrative experience influence the participative pattern, which is one mode of situational leadership. Al-Mawajdeh's (2003) study was conducted as a result of teachers' perceptions of the leadership role played by their principals, using situational theory at an average of all levels. There are statistically significant differences in teachers' qualifications and years of experience. Carnes (2007), showed that the responsibilities for introducing change and implementing different regulatory procedures are a consensus of shared responsibility towards an effective school environment. The study also tried to find an optimal solution by identifying the need for school principals to train in situational leadership, taking into account teachers' perceptions of the characteristics of situational leadership and leaders' orientations to benefit them in issuing standards in this regard, especially in a changing world that faces significant contemporary challenges in the field of educational administration. Al-Mundhari (2009) suggested a number of procedures to activate situational leadership in primary schools in Oman. Al-Thima 
(2010) showed that women leaders and subordinates in Jordanian universities agreed that the most-used pattern of situational leadership was delegate and the least-used directive. Al-Shammari (2010) showed that principals exercise situational leadership to a moderate degree. Copper (2011) found that most school principals prefer to employ situational leadership in their technical and administrative fields, and that male school principals employ it more than females. Ruili (2012) found no statistically significant differences attributable to specialization or qualifications. Colette (2012) showed that situational leadership is better than educational leadership, and that the former helps predict better levels of student achievement than the latter, noting that if assistant principals are trained in situational leadership skills, they can have a significant impact on student achievement, thereby bridging the achievement gap. Al-Babtin (2013) showed that the reporting method ranked first, followed by the participative, the persuasive, and finally the delegative leadership styles. Al-Mutairi (2013) found that the participative method ranked first among the prevailing situational leadership methods, followed by the persuasive, then the directive, and finally the delegative. There were significant differences attributable to age and work experience, but none to qualification. Bin Ibrahim (2015) showed that delegative leadership is the dominant and most appropriate practice among the principals of high schools, followed by the consultative method, and then the directive and participative patterns. It found no statistically significant differences attributable to gender, experience or social status, but statistically significant differences attributable to age. Hammad (2017) showed that the empowerment of employees is positively influenced by the situational leadership of the principal, although with differences among the members of the study sample.

With regard to studies on the achievement motive, Al-Anzi (2003) found a statistically significant correlation between self-confidence and the motivation of achievement of outstanding students, which did not exist among ordinary students. Willke (2004) found a statistically significant impact on the teacher's ability to achieve educational strategies effectively, while teachers from the science disciplines showed a greater level of motivation to achieve than teachers from the humanities. Avyoock (2005) found a positive and statistically functioning relationship between the teacher's teaching effectiveness and his motivation of achievement. Melhem (2008) found no differences on the scale of behaviour disorders attributable to housing variables, social status, or the interaction between them. However, differences in the educational level were recorded in favour of female students, and differences in the motivation of achievement attributable to both the level of education and achievement; there was a statistical correlation between behaviour disorders, educational achievement, and the motivation of achievement. Yaqoob (2012) found that the majority of the sample members showed an intermediate level of self-awareness, that academic achievement was the most predictable from the level of self-perceived competence, and that the motivation of achievement was high. Htouf et al. (2012) showed that the grade of basic education teachers was high, and indicated a positive correlation between the degree of appreciation of the basic education teachers and their level of motivation for achievement. Al-Dinibat (2020) found that the motivation of achievement among teachers in Zarqa governorate was high, with differences due to gender, qualifications and years of experience.

\section{Research Problem}

Based on the role of leadership patterns, including situational leadership in improving the performance of educational institutions and achieving their objectives with better returns, cost and less effort, and believing that administrative standards have become an important necessity to meet the requirements of the current age and improve the competitive advantage of the institution and achieve excellence and creativity, this study seeks to answer the following questions:

Question 1: What is the degree of situational leadership among high school principals in the first Directorate of Education of Amman, from the point of view of teachers?

Question 2: Are there statistically significant differences in the situational leadership among the principals of high schools in the first Directorate of Education of Amman by gender, specialization or years of experience?

Question 3: What is the level of motivation of achievement among teachers in high schools in the first Directorate of Education of Amman, from the point of view of teachers? 
Question 4: Are there statistically significant differences in the level of motivation of achievement for teachers in high schools in the first Directorate of Education of Amman, by gender, specialization or years of experience?

Question 5: Is there a correlation between situational leadership and the level of motivation of achievement among teachers in high schools in the first Directorate of Education of Amman?

\section{Research Method}

The researchers used the descriptive method to achieve the objectives of the study, as itis best suited because it recognizes the degree of situational leadership and its relationship with the motivation of achievement among teachers in Amman from the point of view of teachers.

\section{Study sample}

The study population comprises all 1,105 teachers in the public high schools of the first Directorate of Amman for the 2019/2020 academic year (Ministry of Education Statistics, 2020). The sample consisted of 445 teachers, approximately $40 \%$ of the original population, selected from 23 schools. The study sample was chosen by available method. The demographic variables are listed in Table 1.

Table 1. Distribution of the study sample by demographic variables

\begin{tabular}{|l|l|l|l|}
\hline Variable & Category & Sample & Percentage \\
\hline \multirow{3}{*}{ Gender } & Male & 197 & $44.2 \%$ \\
\cline { 2 - 4 } & Female & 248 & $55.8 \%$ \\
\hline \multirow{2}{*}{$\begin{array}{l}\text { Years of } \\
\text { experience }\end{array}$} & Science & 155 & $34.8 \%$ \\
\cline { 2 - 4 } & Humanities & 290 & $65.2 \%$ \\
\hline Total & Less than 5 years & 112 & $25.1 \%$ \\
\cline { 2 - 4 } & 5-10 years & 148 & $33.2 \%$ \\
\cline { 2 - 4 } & More than 10 years & 185 & $41.7 \%$ \\
\hline
\end{tabular}

\section{Research Methodology}

To collect data, the researchers distributed to the selected teachers a questionnaire on, first, the degree of situational leadership of the principals of their schools and, second, their own level of motivation of achievement. The data was analyzed to find the correlation. The authors developed the first part of the questionnaire after surveying the specifications used in previous scales, including those of Al-Shammari (2010), Colette(2012), Al Mutairi (2013) and Hammad (2017). The second section of the questionnaire was developed from scales for the motivation of achievement, including those of Al-Anzi (2003), Yaqoob (2012) and Htouf (2012).

The participants' answers were measured on a five-Likert scale: I strongly agree (5), I agree (4), neutral (3), I do not agree (2), I never agree (1). In addition to these responses, the arithmetic mean of each item was calculated and labeled as follows:, thus eliminating the maximum minimum equal to (4), and then dividing the difference by (5) the length of the category (0.80) and therefore the arithmetic mean for estimating the responses of the study sample members to performance as follows 1-1.80 represented a very low grade, $1.81-2.60$ a low grade, 2.61-3.40 an average grade, 3.41-4.20 a high grade and 4.21-5 a very high grade.

\section{Research methodology reliability}

To verify the reliability of two parts of the questionnaire, both were presented in their initial form to a group of arbitrators, in order to take advantage of their observations on the appropriateness, clarity and suitability of the phrases, the accuracy of the language formulation and the possibility of adding or deleting paragraphs they deemed appropriate. Based on their observations, some modifications were made to the final form.

To ensure the reliability of the study instruments, the internal consistency of the items in the two scales was assessed by the Cronbach's Alpha calculation, as shown in Table 2. 
Table 2. Internal consistency of the questionnaire

\begin{tabular}{|l|l|}
\hline Variable & Cronbach's Alpha \\
\hline Situational leadership & 0.92 \\
\hline Motivation of achievement & 0.90 \\
\hline
\end{tabular}

\section{Study Procedures}

To achieve the objectives of the study, the following procedures were followed:

- Obtaining an official letter to facilitate the task of the researchers in applying the study tool.

- Preparing the study tool, checking reliability and stability.

- Identifying members of the study population by referring to the official records of the Ministry of Education, the first Directorate of Education of Amman as well as obtaining the official numbers of teachers. A random sample of 445 was achieved.

- Distribution of the questionnaire to the study sample for data collection; clarification that the responses would be used only for scientific research purposes.

-After collected data Kolmogrov-Smimov test were used to check the normal distribution of the data, and test of Homogeneity of variance were used.

- Checking the completed questionnaires to ensure that they were valid for statistical analysis purposes, and to classify them according to the study variables.

- Statistically processing and interpreting data using the Statistical Program for the Social Sciences (SPSS) discussing it, and writing recommendations.

\section{Results}

\section{Research findings}

Question 1: What is the degree of situational leadership among high school principals in the first Directorate of Education of Amman, from the point of view of teachers?

To answer this question, the arithmetic means and standard deviations were calculated, as shown in Table 3, and found to be high.

Table 3. Arithmetic means and standard deviations of study sample responses about situational leadership patterns

\begin{tabular}{|l|l|l|l|l|l|}
\hline Number & Pattern & $\begin{array}{l}\text { Arithmetic } \\
\text { mean }\end{array}$ & $\begin{array}{l}\text { Standard } \\
\text { deviation }\end{array}$ & $\begin{array}{l}\text { Pattern } \\
\text { order }\end{array}$ & grade \\
\hline 1 & $\begin{array}{l}\text { Delegative } \\
\text { leadership }\end{array}$ & 3.53 & 0.65 & 3 & High \\
\hline 2 & $\begin{array}{l}\text { Participative } \\
\text { leadership }\end{array}$ & 3.71 & 0.71 & 1 & High \\
\hline 3 & $\begin{array}{l}\text { Consultative } \\
\text { leadership }\end{array}$ & 3.60 & 0.69 & 2 & High \\
\hline 4 & $\begin{array}{l}\text { Directive } \\
\text { leadership }\end{array}$ & 3.18 & 0.60 & 4 & Intermediate \\
\hline Total & & 3.51 & 0.58 & & High \\
\hline
\end{tabular}

Question 2: Are there statistically significant differences in the situational leadership among the principals of high schools in the first Directorate of Education of Amman by gender, specialization or years of experience?

In addition to the arithmetic means and standard deviations the T-test was calculated for situational leadership patterns, by each of the study variables, as shown in Tables 4-7. 


\section{Gender}

Table 4. Arithmetic means and T-test results to indicate differences of situational leadership by gender

\begin{tabular}{|c|c|c|c|c|c|c|c|}
\hline Pattern & $\begin{array}{l}\text { Gender } \\
\text { variable }\end{array}$ & number & $\begin{array}{l}\text { Arithmetic } \\
\text { mean }\end{array}$ & $\begin{array}{l}\text { Standard } \\
\text { deviation }\end{array}$ & $\begin{array}{l}\text { Degree } \\
\text { of } \\
\text { freedom }\end{array}$ & $\begin{array}{l}\mathrm{T} \\
\text { value }\end{array}$ & $\begin{array}{l}\text { Statistical } \\
\text { significance }\end{array}$ \\
\hline \multirow{2}{*}{$\begin{array}{l}\text { Directive } \\
\text { leadership }\end{array}$} & Males & 197 & 3.19 & 0.69 & \multirow{2}{*}{443} & \multirow{2}{*}{0.116} & \multirow{2}{*}{0.90} \\
\hline & Females & 248 & 3.17 & 0.77 & & & \\
\hline \multirow{2}{*}{$\begin{array}{l}\text { Consultative } \\
\text { leadership }\end{array}$} & Males & 197 & 3.49 & 0.66 & \multirow[t]{2}{*}{443} & \multirow{2}{*}{-1.79} & \multirow{2}{*}{0.07} \\
\hline & Females & 248 & 3.64 & 0.61 & & & \\
\hline \multirow{2}{*}{$\begin{array}{l}\text { Participative } \\
\text { leadership }\end{array}$} & Males & 197 & 3.65 & 0.71 & \multirow[t]{2}{*}{443} & \multirow{2}{*}{-4.220} & \multirow{2}{*}{$0.00^{*}$} \\
\hline & Females & 248 & 3.91 & 0.59 & & & \\
\hline \multirow{2}{*}{$\begin{array}{l}\text { Delegative } \\
\text { leadership }\end{array}$} & Males & 197 & 3.43 & 0.53 & \multirow[t]{2}{*}{443} & \multirow{2}{*}{-1.85} & \multirow{2}{*}{0.06} \\
\hline & Females & 248 & 3.55 & 0.49 & & & \\
\hline \multirow{2}{*}{$\begin{array}{l}\text { Total } \\
\text { patterns }\end{array}$} & Males & 197 & 3.44 & 0.56 & \multirow[t]{2}{*}{443} & \multirow{2}{*}{-1.72} & \multirow{2}{*}{0.07} \\
\hline & Females & 248 & 3.57 & 0.50 & & & \\
\hline
\end{tabular}

Table 4 shows that there are no statistically significant differences at the level of significance $(\alpha=0.05)$ in the degree of exercise of situational leadership patterns and subscales: (directive leadership, consultative leadership, and delegative leadership) by gender. Table 4 also showed that there are statistically significant differences at the level of $(\alpha=0.05)$ in the level of participative leadership, in favour female teachers.

\section{Discipline}

Table 5. Arithmetic means and T-test results to indicate differences of situational leadership by discipline

\begin{tabular}{|c|c|c|c|c|c|c|c|}
\hline Pattern & $\begin{array}{l}\text { Discipline } \\
\text { variable }\end{array}$ & number & $\begin{array}{l}\text { Arithmetic } \\
\text { mean }\end{array}$ & $\begin{array}{l}\text { Standard } \\
\text { deviation }\end{array}$ & $\begin{array}{l}\text { Degree } \\
\text { of } \\
\text { freedom }\end{array}$ & $\begin{array}{l}\mathrm{T} \\
\text { value }\end{array}$ & $\begin{array}{l}\text { Statistical } \\
\text { significance }\end{array}$ \\
\hline \multirow{2}{*}{$\begin{array}{l}\text { Directive } \\
\text { leadership }\end{array}$} & Humanities & 290 & 3.08 & 0.66 & \multirow{2}{*}{443} & \multirow{2}{*}{-2.40} & \multirow{2}{*}{0.01} \\
\hline & Science & 155 & 3.28 & 0.74 & & & \\
\hline \multirow{2}{*}{$\begin{array}{l}\text { Consultative } \\
\text { leadership }\end{array}$} & Humanities & 290 & 3.45 & 0.61 & \multirow[t]{2}{*}{443} & \multirow{2}{*}{-2.50} & \multirow{2}{*}{0.02} \\
\hline & Science & 155 & 3.61 & 0.69 & & & \\
\hline \multirow{2}{*}{$\begin{array}{l}\text { Participative } \\
\text { leadership }\end{array}$} & Humanities & 290 & 3.62 & 0.70 & \multirow[t]{2}{*}{443} & \multirow{2}{*}{-2.49} & \multirow{2}{*}{0.01} \\
\hline & Science & 155 & 3.81 & 0.67 & & & \\
\hline \multirow{2}{*}{$\begin{array}{l}\text { Delegative } \\
\text { leadership }\end{array}$} & Humanities & 290 & $3 \cdot 36$ & 0.50 & \multirow[t]{2}{*}{443} & \multirow{2}{*}{-3.18} & \multirow{2}{*}{0.01} \\
\hline & Science & 155 & 3.55 & 0.53 & & & \\
\hline \multirow{2}{*}{$\begin{array}{l}\text { Total } \\
\text { patterns }\end{array}$} & Humanities & 290 & 3.38 & 0.55 & \multirow{2}{*}{443} & \multirow{2}{*}{-3.30} & \multirow{2}{*}{0.00} \\
\hline & Science & 155 & 3.56 & 0.56 & & & \\
\hline
\end{tabular}

Table 5 indicates that there are statistically significant differences at the level of significance $(\alpha=0.05)$ between the responses of the study sample in all areas and patterns combined by the variable of discipline. 


\section{Years of experience}

Table 6. Arithmetic means to indicate differences of situational leadership by years of experience

\begin{tabular}{|c|c|c|c|c|}
\hline Pattern & Category & Number & Arithmetic mean & Standard deviation \\
\hline \multirow[t]{3}{*}{$\begin{array}{l}\text { Directive } \\
\text { leadership }\end{array}$} & Less than 5 years & 112 & 3.10 & 0.63 \\
\hline & 5-10 years & 148 & 3.19 & 0.73 \\
\hline & More than 10 years & 185 & 3.23 & 0.74 \\
\hline \multirow{3}{*}{$\begin{array}{l}\text { Consultative } \\
\text { leadership }\end{array}$} & Less than 5 years & 112 & 3.66 & 0.60 \\
\hline & 5-10 years & 148 & 3.48 & 0.64 \\
\hline & More than 10 years & 185 & 3.49 & 0.68 \\
\hline \multirow[t]{3}{*}{$\begin{array}{l}\text { Participative } \\
\text { leadership }\end{array}$} & Less than 5 years & 112 & 3.82 & 0.62 \\
\hline & 5-10 years & 148 & 3.64 & 0.71 \\
\hline & More than 10 years & 185 & 3.71 & 0.72 \\
\hline \multirow{3}{*}{$\begin{array}{l}\text { Delegative } \\
\text { leadership }\end{array}$} & Less than 5 years & 112 & 3.50 & 0.47 \\
\hline & 5-10 years & 148 & 3.42 & 0.54 \\
\hline & More than 10 years & 185 & 3.46 & 0.54 \\
\hline \multirow[t]{3}{*}{ Total patterns } & Less than 5 years & 112 & 3.18 & 0.71 \\
\hline & $5-10$ years & 148 & 3.53 & 0.65 \\
\hline & More than 10 years & 185 & 3.72 & 0.69 \\
\hline
\end{tabular}

Table 6 indicates apparent differences between the arithmetic means of the situational leadership by years of experience.

Table 7. One-way analysis of variance (ANOVA) test results to indicate differences of situational leadership by years of experience

\begin{tabular}{|c|c|c|c|c|c|c|}
\hline Pattern & $\begin{array}{l}\text { Source of } \\
\text { variance }\end{array}$ & $\begin{array}{l}\text { Sum of } \\
\text { squares }\end{array}$ & $\begin{array}{l}\text { Degree of } \\
\text { freedom }\end{array}$ & $\begin{array}{l}\text { Squar } \\
\text { es } \\
\text { mean }\end{array}$ & F value & Level of significance \\
\hline \multirow[t]{3}{*}{$\begin{array}{l}\text { Directive } \\
\text { leadership }\end{array}$} & $\begin{array}{l}\text { Between } \\
\text { groups }\end{array}$ & 0.775 & 2 & 0.39 & \multirow{3}{*}{0.77} & \multirow{3}{*}{0.446} \\
\hline & $\begin{array}{l}\text { Within } \\
\text { groups }\end{array}$ & 155.84 & 442 & 0.51 & & \\
\hline & Total & 156.614 & 444 & & & \\
\hline \multirow{3}{*}{$\begin{array}{l}\text { Consultative } \\
\text { leadership }\end{array}$} & $\begin{array}{l}\text { Between } \\
\text { groups }\end{array}$ & 1.728 & 2 & 0.86 & \multirow{3}{*}{2.05} & \multirow{3}{*}{0.131} \\
\hline & $\begin{array}{l}\text { Within } \\
\text { groups }\end{array}$ & 130.046 & 442 & 0.42 & & \\
\hline & Total & 131.774 & 444 & & & \\
\hline \multirow[t]{2}{*}{$\begin{array}{l}\text { Participative } \\
\text { leadership }\end{array}$} & $\begin{array}{l}\text { Between } \\
\text { groups }\end{array}$ & 1.545 & 2 & 0.77 & \multirow{2}{*}{1.62} & \multirow{2}{*}{0.199} \\
\hline & $\begin{array}{l}\text { Within } \\
\text { groups }\end{array}$ & 146.618 & 442 & 0.48 & & \\
\hline
\end{tabular}




\begin{tabular}{|l|l|r|r|r|r|r|}
\hline & Total & 148.163 & 444 & & & \\
\hline \multirow{3}{*}{$\begin{array}{l}\text { Delegative } \\
\text { leadership }\end{array}$} & $\begin{array}{l}\text { Between } \\
\text { groups }\end{array}$ & 0.287 & 2 & 0.14 & & \\
\cline { 2 - 5 } & $\begin{array}{l}\text { Within } \\
\text { groups }\end{array}$ & 83.998 & 442 & 0.27 & 0.53 & 0.592 \\
\cline { 2 - 5 } & Total & 84.285 & 444 & & \\
\cline { 1 - 5 } $\begin{array}{l}\text { Total } \\
\text { patterns }\end{array}$ & $\begin{array}{l}\text { Between } \\
\text { groups }\end{array}$ & 1.904 & 2 & 0.95 & & \\
\cline { 2 - 5 } & $\begin{array}{l}\text { Within } \\
\text { groups }\end{array}$ & 154.711 & 442 & 0.50 & 1.90 & \multirow{2}{*}{0.152} \\
\cline { 2 - 5 } & Total & 156.614 & 444 & & \\
\hline
\end{tabular}

Table 7 indicates that there are no statistically significant differences at the level of significance $(\alpha=0.05)$ in situational leadership by years of experience.

Question 3: What is the level of motivation of achievement among teachers in high schools in the first Directorate of Education of Amman, from the point of view of teachers?

To answer this question, the arithmetic means and standard deviations were calculated, with the results as shown in Table 8.

Table 8. Arithmetic means and standard deviations of the responses about the level of motivation of achievement among teachers

\begin{tabular}{|l|l|l|l|}
\hline Variables & Arithmetic mean & Standard deviation & Level \\
\hline $\begin{array}{l}\text { Motivation of } \\
\text { achievement }\end{array}$ & 3.84 & 0.54 & High \\
\hline
\end{tabular}
high.

It appears from Table 8 that the level of motivation of achievement among the teachers is

Question 4: Are there statistically significant differences in the level of motivation of achievement for teachers in high schools in the first Directorate of Education of Ammanby gender, specialization or years of experience?

\section{First: gender and discipline}

To answer this question, the arithmetic means and standard deviations were calculated, using the T-test to reveal the significance of the differences in the level of motivation of achievement by gender orqualification, as shown in Table 9.

Table 9. Arithmetic means, standard deviations and $\mathrm{T}$ test results to indicate differences in the level of motivation of achievement by gender and discipline

\begin{tabular}{|l|l|l|l|l|l|l|l|}
\hline Variable & category & number & $\begin{array}{l}\text { Arithmetic } \\
\text { means }\end{array}$ & $\begin{array}{l}\text { standard } \\
\text { deviations }\end{array}$ & $\begin{array}{l}\text { Degree } \\
\text { of } \\
\text { freedom }\end{array}$ & $\begin{array}{l}\text { T } \\
\text { value }\end{array}$ & $\begin{array}{l}\text { Level of } \\
\text { significance }\end{array}$ \\
\hline \multirow{2}{*}{ Gender } & Male & 197 & 3.73 & 0.52 & 443 & -4.00 & 0.00 \\
\cline { 2 - 6 } & Female & 248 & 3.93 & 0.54 & & & \\
\cline { 1 - 7 } Discipline & Humanities & 290 & 3.83 & 0.55 & 443 & - & 0.00 \\
\cline { 2 - 5 } & Science & 155 & 3.97 & 0.39 & & 2.810 & \\
\hline
\end{tabular}

Table 9 shows that there are statistically significant differences at the level of significance $(\alpha \leq 0.05)$ in the level of teachers' motivation of achievement by gender and by discipline, a as indicated by the $\mathrm{T}$ values. The differences were in favour of female science teachers. 


\section{Second: Years of experience}

Arithmetic means and standard deviations were calculated, and the one-way variance test ANOVA was used to determine the differences, as shown in Table 10.

Table 10. Arithmetic means and ANOVA test results to indicate differences in the level of motivation of achievement by years of experience

\begin{tabular}{|l|l|l|l|l|l|l|}
\hline Measure & $\begin{array}{l}\text { Source of } \\
\text { variance }\end{array}$ & $\begin{array}{l}\text { Sum of } \\
\text { Squares }\end{array}$ & $\begin{array}{l}\text { Degree of } \\
\text { freedom }\end{array}$ & $\begin{array}{l}\text { Squares } \\
\text { mean }\end{array}$ & F value & Level of significance \\
\hline $\begin{array}{l}\text { Motivation } \\
\text { of } \\
\text { achievement }\end{array}$ & $\begin{array}{l}\text { Between } \\
\text { groups }\end{array}$ & 3.46 & 2 & 1.73 & 4.269 & 0.01 \\
\cline { 2 - 5 } & $\begin{array}{l}\text { Within } \\
\text { groups }\end{array}$ & 158.06 & 442 & 0.41 & & \\
\cline { 2 - 6 } & Total & 160.52 & 444 & & \\
\hline
\end{tabular}

Table 10 shows statistically significant differences at the level of indication $(\alpha=0.05)$ between the responses of the study sample by years of experience.

The Scheffe test was used for dimensional comparisons, as shown in Table 11.

Table 11. Scheffe test for dimensional comparisons of arithmetic means of responses about the motivation of achievement by years of experience

\begin{tabular}{|l|l|l|l|l|l|}
\hline Measure & $\begin{array}{l}\text { Years of } \\
\text { experience }\end{array}$ & $\begin{array}{l}\text { Arithmetic } \\
\text { means }\end{array}$ & $\begin{array}{l}\text { Less than } 5 \\
\text { years }\end{array}$ & 5 -10 years & $\begin{array}{l}\text { More than 10 } \\
\text { years }\end{array}$ \\
\hline $\begin{array}{l}\text { Motivation of } \\
\text { achievement }\end{array}$ & $\begin{array}{l}\text { Less than } 5 \\
\text { years }\end{array}$ & 3.70 & ---- & $0.189^{*}$ & 0.202 \\
\cline { 2 - 6 } & \begin{tabular}{l} 
5-10 years \\
\cline { 2 - 6 } \\
More than 10 \\
years
\end{tabular} & 3.89 & 0.189 & ---- & $0.013^{*}$ \\
\hline
\end{tabular}

Table 11 shows statistical differences at the level of statistical indication $(\alpha=0.05)$ of the level of motivation of achievement by years of experience, in favour of teachers with 5-10 years of experience.

Question 5: Is there a correlation between situational leadership and the level of motivation of achievement among teachers in high schools in the first Directorate of Education of Amman?

To answer this question, the coefficient (Pearson Correlation) was extracted between the situational leadership practice and the level of motivation of achievement among teachers, as shown in Table 12.

Table 12. Results of extracting the value of Pearson correlation coefficient between the degree of situational leadership and the level of motivation of achievement among teachers

\begin{tabular}{|l|l|}
\hline Variable & Motivation of achievement \\
\hline Situational administration & $0.52^{*}$ \\
\hline
\end{tabular}

Table 12 shows a positive correlation between the degree of situational leadership of high school principals and the level of motivation achievement among teachers, where the value of the Pearson correlation coefficient (0.52) is a value of statistical significance.

\section{Discussion}

The results of the first question showed that principals' practice of situational leadership was high. This may be because the Ministry of Education, among its strategic plans to qualify its staff as administrators, has involved them in training courses in educational leadership. School principals thus have the administrative ability to deal with situations wisely, as these courses are largely 
focused on the roles and skills of the leader and on dealing with team work to solve the problems, difficulties and challenges facing principals, through the employment of communication skills. These are the roles stressed in the educational leadership courses. Naseer (2017) pointed out that the principal's multiple skills in administration contribute to his ability to deal with different situations in a balanced administrative manner.

The results of this study are consistent with those results of Al-Aghbari (1998), which indicated that the principal's pattern of leadership supports him in completing his tasks. They also agree with Thimma (2010), Babtain (2013) and Bin Ibrahim (2015), who indicated the importance of the leadership style in completing the tasks required of the principal, as shown by the principals who underwent training courses.

However, our results differ from those of Muwajda (2003) and Al-Shammari (2010) who revealed teachers' perceptions of the leadership role played by their principals at an intermediate level. Al-Mutairi (2013) also showed that the delegative pattern came in last place among the patterns of situational leadership.

The results also showed that there were no statistically significant differences between the responses of the study sample in all patterns by gender. This can be explained by the similarity of teachers' judgment in situations and the environment regardless of their gender, due to the situational leadership practiced by their principals; this includes concern for human relations within the limits of employment, mutual influence between personal aspects and social circumstances, participation in decision-making and, finally, acting appropriately according to the situation.

It also showed statistically significant differences in the responses of the study sample by discipline and years of experience. This can be explained by the fact that each teacher has unique experience, making it a fundamental variable that may play an important role in the thinking and style of the teachers, and their judgment on their principal. Those who have 5-10 years of experience evaluate their principal through being sufficiently familiar with what his he has to do. However, teachers with less experience will assess him differently, while those with more than 10 years will give a better rating. These results are consistent with those of Bin Ibrahim (2015), Al-Thima (2010) and Muwajda (2003), which showed no differences in the sample's estimates of situational leadership patterns attributable to gender. Ruilly (2012) found no statistically significant differences between the mean estimates of the study sample in all areas of the study for discipline. The results of this study are also consistent with those of Al Mutairi (2013), which indicated no differences in terms of discipline. However, our results differed from those of Oujda (2002) in part by the presence of statistically significant differences in qualifications of teachers and consistent with less experience. Finally, our results correspond to those of Ireh and Bailley (1999), which indicated statistically significant differences in years of administrative experience affecting the type of participation, one of the distinctions of situational leadership. The reason may be the existence of statistically significant differences in experience; experience is important in the progress and development of the educational institution. The more experience possessed by the school principal, the better the development and growth of the school.

The results showed that the level of motivation of achievement of high school teachers in the first Directorate of Education of Amman was high. This can be explained as a positive indicator of success, as these schools have achieved a kind of compatibility or harmony between their objectives and those of their employees. Also, the excellence of administration among principals may have raised the level of motivation among teachers, as they become interested in working and providing initiatives and innovations that arise in the field of science in the school through their acceptance of the work.

Similarly, Imran (2000) pointed out that the motivation for achievement in the teacher lies in an interest in education and development, which is an internal condition for greater effort and activity on work and continuity; Al-Qurashi (2012) also emphasized that the personal characteristics of those who are motivated to accomplish are more inclined to self-confidence. The results of this study were in agreement with those on the subject of motivation of achievement, with a high level, including Tabashi (2007) and Htouf et al. (2012).

The results from the tables show statistically significant differences in the level of teachers' motivation of achievement from the point of view of the teachers themselves by gender and qualification. This can be explained by the similarity of their current working environments, which helps to achieve a high level of motivation for achievement indifferent gender, qualification, as well 
as the nature and style of administration that may occur in the school work, whether related to their individual goals and needs or to the school's goals and requirements. This may also be the result of the principals' orientation of excellence in work and management and the inclusion of administration for all areas of work in the school, especially the concern for the management of human resources and the achievement of their various requirements. This finding is consistent with the conclusion of Yaqoob (2012), which indicated that the degree of motivation of the study sample was high.

The results showed statistically significant differences between the arithmetic means of the responses of the study sample on the scale of the rate of motivation of achievement by years of experience, in favour of those with 5-10 years of experience. This can be explained by the fact that the more years of experience they have, the more motivated they are to work, which is reflected in the response of the sample members.

The results showed that a positive correlation between the degree of practice of situational leadership in high school principals, and the level of motivation of achievement among teachers. This can be explained as natural if the principals seek administrative excellence and ensure that teachers develop a high level of motivation towards achievement. This study has scientifically confirmed responses according to a descriptive approach based on the collection of information from individuals reflecting the reality of the phenomenon.

This result may also be linked to the fact that excellence in administration or any work requires the motivation of the individual himself, or his employees, and that principals who initiate and create new businesses and activities require him and the employees to be active, energetic and motivated to accomplish, especially when these activities and events serve the public interest and meet the wishes and needs of the employees.

\section{Conclusion and recommendations}

- Arranging courses for principals to inform them of the importance, objectives and dimensions of these patterns and to focus on the directive leadership style based on the provision of instructions and guidance.

- Providing decision makers and educational leaders in the Ministry of Education and its principals with the results of this study in order to make plans to spread situational leadership patterns among school principals, and to take the necessary measures to achieve the desired educational goals.

- Providing decision makers and educational leaders in the Ministry of Education with the results of this study to examine ways to improve the working conditions of teachers and increase their motivation, and to establish a system of material and moral incentives throughout their careers.

- Further studies and research in high schools on the relationship between situational leadership practice and creativity, organizational citizenship behaviour and the organizational climate.

- Strengthening situational leadership patterns among high school principals, and creating an annual award for outstanding school principals.

\section{References}

Abesha, 2012 - Abesha, A. (2012). Effects of Parenting Styles ‘ Academic Self-Efficacyand Academic Motivation on the Academic Achievement Of University Students in Ethiopia. Unpublished Doctoral Dissertation, University Of Cown.

Abkar, 2015 - Abkar, Q. (2015). Leadership Behavior of The Principals of public high Schools and its relationship with the level of teachers performance field study in Khartoum State. Unpublished Doctoral Dissertation, Faculty of Education, Omdurman University, Islamic, Sudan.

Abu Al-Kashk, 2015 - Abu Al-Kashk, M. (2015). Contemporary School Administration. Jarir Publishing and Distribution House, Amman, Jordan.

Al Saud, 2009 - Al Saud, R. (2009). Educational Department Concepts and Horizons. Tariq Office Services, Amman, Jordan.

Al-Ajarma, 2012 - Al-Ajarma, M. (2012). The prevailing leadership patterns among the principals of private schools and their relationship with the quality of education from the point of 
view of teachers in the governorate of the capital Amman. Unpublished Master Thesis, Middle East University, Amman, Jordan.

Al-Anzi, 2003 - Al-Anzi, S. (2003). Self-confidence and its relationship with the motivation of achievement among students who are academically and ordinary in the middle school in Arar. Unpublished master Thesis, Um al-Qura University, Mecca.

Al-Azzam, 2010 - Al-Azzam, A.N. (2010). Family Climate and its Relationship with Jordanian Students. Unpublished Master Thesis, Yarmouk University, Jordan.

Al-Babtain, 2013 - Al-Babtain, A. (2013). The reality of practicing the leadership methods of high school principals in Riyadh. Unpublished Master Thesis, Hashemite University, Amman, Jordan.

Al-Dari, Al Qasimiyah, 2020 - Al-Dari, H., Al Qasimiyah, A. (2020). The impact of democratic leadership on job satisfaction among teachers of schools in Al Ain City. Arab Journal of Educational and Psychological Sciences. 4(17): 211-240.

Al-Dinibat, 2020 - Al-Dinibat, G. (2020). Degree of Administrative Excellence among the principals of high schools in Zarqa governorate and its relationship with the level of achievement motive among teachers. Unpublished Master Thesis, Hashemite University, Zarqa, Jordan.

Al-Farmawi, 2004 - Al-Farmawi, H. (2004). Human Motivation between Innovative Theories and Contemporary Trends. Arab Thought House, Cairo.

Al-Harbi, 2008 - Al-Harbi, Q. (2008). Modern Educational Command. Janadriyah Publishing and Distribution, Amman, Jordan.

Al-Hilal, 2011 - Al-Hilal, I. (2011). The Impact of the Use of NLP in the Development of the Palestinian Teacher's Achievement Drive. Al-Quds Open University Journal of Research and Studies. 3(4): 81-110.

Al-Mashhrfi, 2015 - Al-Mashhrfi, S. (2015). Leadership Styles prevailing among principals and high school principals in Oman: Analytical study. Faculty of Education Journal. 25(2): 473-509.

Al-Mudiscussion, 2007 - Al-Mudiscussion, S. (2007). Leadership above the community and leadership with the community. Journal of Education and Psychology. 28: 35-54.

Al-Mutairi, 2013 - Al-Mutairi, K. (2013). Situational leadership and its role in promoting organizational loyalty among subordinates in jeddah passport administration. Unpublished Master Thesis, Nayef Arab University for Security Sciences, Riyadh.

Al-Qaisi, 2010 - Al-Qaisi, H. (2010). Educational Department, Principles and Theories Modern Trends. Dar al-Curriculum for Publishing and Distribution, Amman.

Al-Qurashi, 2012 - Al-Qurashi, M. (2012). The achievement motive and its relationship to the concern of the future in a sample of students of Um al-Qura University.Unpublished Master Thesis, Um al-Qura University, Mecca.

Al-Sarafi, 2009 - Al-Sarafi, M. (2009). Scientific Encyclopedia of Organizational Behavior, Analysis at the Community Level. Modern University Office, Alexandria.

Al-Shahrani, 2013 - Al-Shahrani, A. (2013). The prevailing leadership style among school principals in Bisha province and its relationship to the job satisfaction of teachers. Unpublished Master's Thesis, Al Baha University, Riyadh, Saudi Arabia.

Al-Tawhari, 2006 - Al-Tawhari, M. (2006). The Motivation for Achievement. Al-Fikr Publishing and Distribution House, Amman.

Al-Thima, 2010 - Al-Thima, G. (2010). Degree of practice of women academic leaders at Jordanian universities for attitude leadership patterns and their relationship to psychological combustion in their subordinates. Unpublished Master Thesis, Hashemite University, Zarqa, Jordan.

Al-Yousef, 2010 - Al-Yousef, R. (2010). Educational Psychology between Theory and Classroom Applications. Al-Andalus Printing and Publishing House, Hail, Saudi Arabia.

Avci, 2016 - Avci, A. (2016). Effect of Leadership Styles of School Principals on Organizational Citizenship Behaviors. Educational Research Review. 11: 1008-1024.

Avyoock, 2005 - Avyoock, P. (2005). The Mississippi student achievement improvement act and the no child left behind act: Leadership and teacher motivation. Dissertation Abstracts International. V. 64. 09A. AA13103678.

Ayasra, 2006 - Ayasra, A. (2006). Leadership and Realism in Educational Management. Al-Hamid Publishing and Distribution House, Amman, Jordan. 
Barakat, Hassan, 2011 - Barakat, Z., Hassan, K. (2011). Teachers' educational competences, level of practice and their relationship to motivation for achievement. Al Quds Open University Journal of Research and Studies. 24(1): 37-84.

Calvo, 2006 - Calvo, M. (2006). Using Enablers of the EFQM Model to Manage Institutions of Higher Education Quality Assurance in Education. An International Perspective ERIC. (14)2: 99-122.

Copper, 2011 - Copper, R. (2011). The Degree of situational Administration Departments American Schools, PHD degree University of Calgary, Canada. Proudest Dissertation Abstracts International. 52(5): 1587 .

Faraj, 2016 - Faraj, N. (2016). The prevailing patterns of educational leadership among the principals and principals of the main practice in Sulaimaniyah from the point of view of the faculty members. Journal of Faculty of Arts. 118: 553-572.

Faroh, 2011 - Faroh, B. (2011). Psychosocial Compatibility and Its Relationship to The Motivation to Learn in A Teenager In Secondary Education. Unpublished Master Thesis, Mouloud Mamari University, Algeria.

Ghabari, 2008 - Ghabari, T. (2008). Theoretical Motivation and Practice. Al-Marcha Publishing and Candles, Amman, Jordan.

Govern, Perti, 2004 - Govern, J., Perti, H. (2004). Motivation. Theory Research and Perti. H and wsdsworth . Application Thomason, Australia.

Haji, 1998 - Haji, A. (1998). Educational and School Administration. Arab Thought House, Cairo, Egypt.

Hamadat, 2017 - Hamadat, $M$. (2017). Educational Department of Contemporary Jobs and Issues. Al-Hamid Publishing and Distribution House, Amman, Jordan.

Harem, 2004 - Harem, H. (2004). Organizational behaviour of individuals and groups in business organizations. Dar al-Hamid, Jordan.

Imran, 2014 - Imran, M. (2014). Habits of reason and its relationship to problem solving strategy - a comparative study between outstanding and ordinary students. Unpublished Master Thesis, Faculty of Education, Al-Azhar University, Egypt.

Khalifa, 1993 - Khalifa, S. (1993). Motivation for Achievement. Dar Ghraib Printing and Publishing, Cairo, Egypt.

Naseer, 2017 - Naseer, A. (2017). Leadership patterns among public school principals and their relationship to the conduct of organizational citizenship of teachers in Zarqa governorate. Unpublished Master Thesis, Hashemite University, Zarqa.

Nawafala, 2002 - Nawafala, M. (2002). Educational Positioning Department in the Qur'an.Dar Majdlawi, Amman, Jordan.

Omari, 2009 - Omari, Q. (2009). Administration leadership patterns and their impact on the success of public organizations. Unpublished Doctoral Thesis, University of St Clemens.

Ruwaili, 2012 - Ruwaili, M. (2012). Perceptions of private school teachers for the exercise of their principals' leadership role using the theory of position in al-Qurayat governorate. Journal of the Faculty of Education in Mansoura. 11(81): 312-346.

Tamimi, 2006 - Tamimi, A. (2006). Evaluation and measurement of the performance of educational supervisors and specialists. Journal of Educational and Psychological Sciences. 7(3): 146-174.

Wadis, 2000 - Wadis, H. (2000). Analysis of students' motivations to learn to swim according to sms model. Unpublished Doctoral Thesis, Yarmouk University, Jordan.

Willke, 2004 - Willke, R. (2004). The effect of active learning on college students' achievement, motivation, and self-efficacy in a human physiology course for non-majors. Dissertation Abstracts International. V. 61. 11A. AA19992936.

Zahrani, 2008 - Zahrani, N. (2008). The relationship of the leadership style of school principals to the morale of the primary school teachers in Jeddah. Unpublished Master Thesis, Um al-Qura University, Saudi Arabia. 